\title{
O TEATRO AFRODIASPÓRICO E RITUALÍSTICO DO NÚCLEO AFRO-BRASILEIRO DE TEATRO DE ALAGOINHAS (NATA)
}

\author{
THE AFRODIASPÓRICO AND RITUALISTIC THEATER \\ OF THE CORE AFRO-BRASILIAN THEATRE OF ALAGOINHAS (NATA)
}

Heverton Luís Barros Reis *

\begin{abstract}
Resumo
O objetivo aqui é refletir sobre as contribuições do teatro negro brasileiro no embate ao racismo, exclusão social, intolerância religiosa e da luta por visibilidade. Tomando como sujeito da narrativa o Núcleo Afro-brasileiro de Teatro de Alagoinhas (NATA). Para além, deseja-se ponderar sobre os possíveis sentidos de teatro do negro; refletindo sobre a construção histórica da negritude nas artes cênicas, a ancestralidade africana e afro-brasileira na cena poética do fazer teatral, assim como o diálogo entre candomblé e teatro proposto pela yakekerê e encenadora/dramaturga Onisajé, pensando os corpos negros dentro e fora dos palcos e a relação arte e política. Para problematização, toma-se a poética afrocênica do espetáculo Exu: a boca do universo.
\end{abstract}

Palavras-chave: Arte Política; Teatro Negro; Candomblé; NATA.

\begin{abstract}
The objective here is to reflect on the contributions of black Brazilian theater in the fight against racism, social exclusion, religious intolerance and the struggle for visibility. It takes as its subject the narrative of the Core Afro-Brasilian Theatre of Alagoinhas (NATA). In addition, we want to consider the possible meanings of black theater; reflecting on the historical construction of blackness in the performing arts, the ancestry within African and Afro-Brazilian in the poetic scene of theatrical making, as well as the dialogue between candomblé and theater proposed by Yakekerê and director/playwright Onisajé; considering black bodies on and off-stage and on the relationship between art and politics. The show Exu: a boca do universo is considered as a problematization of afrocentric poetic.
\end{abstract}

Keywords: Art Policy; Black Theatre; Condomblé; NATA.

\section{Introdução}

No contexto de luta contra o racismo e suas ramificações, procurando promover a visibilidade das questões da cultura afrodiaspórica, nasceu o Núcleo Amador de Teatro e Artes (NATA) no ano de 1998, no Colégio Estadual Polivalente de Alagoinhas, interior da Bahia. O grupo, formado por estudantes, participou do primeiro Festival de Teatro em Destaque promovido pela professora do Colégio, Fátima Salles, recebendo o prêmio de

\footnotetext{
* Mestrando em Estudos Étnicos e Africanos pela Universidade Federal da Bahia (UFBA)/Brasil. E-mail: hevertonbarrosreis@gmail.com.
} 
melhor espetáculo e cenário, bem como o prêmio especial por ser o grupo/espetáculo que mais chamou a atenção do público, lotando o centro cultural da cidade de Alagoinhas.

Ainda na cidade natal, entre os anos de 1998 e 2002, o NATA apresentou os espetáculos: O seco da seca (1998), Tá na cor (1999), Guarda-roupa íntimo (1999) — este último recebeu cinco prêmios, dentre eles o de melhor espetáculo - e Senzalas (2002). E assim surge, de forma embrionária, o que se tornaria o Núcleo Afro-brasileiro de Teatro de Alagoinhas.

A partir de 2004, o NATA passou a se apresentar em Salvador, por intermédio do projeto criado pelo Teatro Vila Velha (TVV), intitulado de Cabo a Rabo, que possibilitou grupos de teatro do interior da Bahia a se apresentarem no tão conhecido teatro da cidade. Em 2004, o NATA apresentou o espetáculo Perfil, e no ano seguinte, a convite dos organizadores do projeto, apresentou a peça A eleição (2005).

Nos anos subsequentes, o NATA começa a se posicionar na luta contra o racismo e intolerância religiosa de forma mais objetiva por meio de seus espetáculos. Esse envolvimento deveu-se muito à presença de Fernanda Júlia Barbosa (Onisajé) ${ }^{1}$ como graduanda no curso de Direção Teatral na Escola de Teatro da Universidade Federal da Bahia (UFBA) e yakekerê ${ }^{2}$ no Terreiro Ilê Axé Oyá Ladê Inan em Alagoinhas.

Dessa maneira, podemos entender o NATA em sua historicidade e em suas memórias afroculturais, ou seja, um grupo com artistas que têm a sensibilidade de compreender a herança africana e afro-brasileira. Um coletivo com posicionamento de luta frente ao racismo estrutural e às discriminações sociais e religiosas.

\section{Lutar e (r)existir: o teatro negro contra o não-lugar}

O racismo engloba muitas indagações. A desumanização, ancorada pela escravidão, influenciou de maneira contundente no processo de coisificação do ser e na opressão de negar as identidades. E esse contexto embasa, por vezes, a discriminação racial na atualidade, assim como o mito da democracia racial que trava a possibilidade de

\footnotetext{
${ }^{1}$ Em respeito à sua escolha ao longo desta escrita, e a partir de agora, sempre que for referir-me a Fernanda Júlia Barbosa (nome social) tratá-la-ei como Onisajé (nome religioso e artístico).

${ }^{2}$ Iaquequerê, iakekerê, yakekerê ou iá-quererê, em iorubá, representa a junção das palavras "pequena" e "mãe", sendo assim, yakekerê é o mesmo que "mãe-pequena".
} 
diálogos, em que, por muito tempo ao longo de nossa história, a cultura branca quis apagar a existência das culturas negras. E dessa forma, dificultou a presença dos negros nas artes cênicas.

\begin{abstract}
A tese do branqueamento baseava-se na presunção da superioridade branca, às vezes pelo uso dos eufemismos raças "mais adiantadas" e pelo fato de ficar em aberto a questão de ser a inferioridade inata. À suposição, juntavam-se mais duas: primeiro - a população negra diminuiria progressivamente em relação à branca. Segundo - a miscigenação produzia "naturalmente" uma população mais clara, em parte porque o gene branco era mais forte e em parte porque as pessoas procurassem parceiros mais claros (SKIDMORE, 2012, p. 81, grifos do autor).
\end{abstract}

Diante desse dilema, entendemos o pensar de Stuart Hall (2010) sobre a necessidade de percebermos que as discussões sobre as identidades ajudam no empoderamento e na autoconfiança, leia-se, autoestima da população negra, pois nota-se todo multiculturalismo existente.

\begin{abstract}
A identidade plenamente unificada, completa, segura e coerente é uma fantasia. Ao invés disso, na medida em que os sistemas de significação e representação cultural se multiplicam, somos confrontados por uma multiplicidade desconcertante e cambiante de identidades possíveis, com cada uma das quais poderíamos nos identificar - ao menos temporariamente. (HALL, 2010, p. 3).
\end{abstract}

Nesse sentido, compreende-se a ausência de uma identidade única, integral e/ou absoluta que defina um povo. É o caso do negro no Brasil, quando entendemos seu contexto histórico, pois não existe um aspecto único para definir essas identidades. Essa construção perpassa a ideia da aparência física e fenotípica, sendo, às vezes, compreendida em uma escolha política e ideológica.

Ao tentar refletir sobre o racismo na sociedade e no teatro, observamos que para Fanon (2010), os processos de opressão contra o negro não devem ser entendidos deslocados das configurações sociais que os fomentam. E embora o livro Pele negra, máscaras brancas tenha sido construído em contextos outros, com temporalidade e espacialidade diferente, pode e deve servir para reflexão das relações desiguais dos variados grupos sociais na perspectiva da negritude, e nesse caso, não só do Brasil/Bahia, mas das múltiplas identidades negras.

Frantz Fanon (2010) defende a tese de que uma sociedade é ou não é racista, nesse segmento caberia aos indivíduos compreender as especificidades dos variados processos 
histórico-sociais. Contudo vale ressaltar que não é uma questão de quantificar qual sociedade é mais ou menos racista. $\mathrm{O}$ interessante é investigar a questão do racismo e pensar sobre nossa historicidade e realidade social, a fim de sobrepujá-las.

Poderia aqui aferir como o racismo cria a sociedade ao mesmo tempo em que a sociedade produz o racismo, em uma via de mão dupla, ou ainda, na contribuição do capitalismo como instrumento de opressão negra e consequentemente de qualificação das classes sociais. Sem falar dos direitos básicos que são negligenciados.

Dentro da lógica capitalista, percebemos a desigual configuração de trabalho, em que os negros, por vezes, estão em postos de menor crédito, e o branco (a branquitude) faz oposição aos negros e indígenas em direitos e privilégios. De maneira geral, o racismo funciona no engendramento de estratificação social concorrendo para conservar o "branco" em prerrogativa de direitos e não em deveres frente aos negros. Porém não tenho como intencionalidade apontar os aspectos do racismo sem confrontá-lo com as lutas e mudanças protagonizadas pelo negro ao longo da história deste país.

Refletir sobre a ideia do negro e os conceitos das palavras negritude e identidades, se faz impreterível para reafirmar o lugar político/poético e estético do negro, e para contribuição e reconfiguração do teatro nacional com seu aporte de afirmação e luta. Portanto é necessário coadjuvar a importância aos artistas independentes e/ou grupos de teatro composto por artistas negros, que no decorrer do século XX foram protagonistas de lutas e visibilidade pela permanência no cenário teatral, como é o caso do Teatro Experimental do Negro (TEN) (1944-1961) que serviu e serve de referência para tantos outros grupos que vieram depois, assim como é referencial teórico e metodológico para o teatro produzido pelo NATA.

O teatro, dentro do universo da cultura e do engendramento social, fabrica e reelabora os variados sentidos, símbolos, signos, valores, bem como modo de vida, e torna-se - com apoio subjetivo da economia e política —, local de permanências hegemônicas, assim como pode converter-se em espaço de desconstrução contra a ordem preponderante. Nesse sentido, cabe a crítica de Chartier (1991), sobre representação:

As formas de teatralização da vida social na sociedade [...] dão o exemplo mais manifesto de uma perversão da relação de representação. Todas visam, de fato, a fazer com que a coisa não tenha existência a não ser na imagem que exibe, 
que a representação mascare ao invés de pintar adequadamente o que é seu referente (CHARTIER, 1991, p. 185).

Para Chartier (1991), representação é o produto que resulta de uma prática. A exemplo, temos a literatura que é a representação em si, que por sua vez, gera um produto das práticas simbólicas, que pode ainda, transformar-se em outras representações. O mesmo ocorre com as artes cênicas e com os teatros negros, que como representação são o produto de prática simbólica. Essas representações provocadas pelo teatro do NATA, seja real ou imaginada, são atribuídas ao possibilitar sentidos.

E é na contramão das falsas representações que os teatros negros surgem, procurando autorrepresentação, descontruindo todo um pensamento de inferioridade, e lutando para que tantos outros se reconheçam para além de um país no qual se escravizou os negros, no qual se tentou e tenta impor a cultura europeizada, branca e ocidentalizada sobre as demais. Mas não se limita a essa visão, pois compreende que as construções simbólicas forjam a sociedade para além das lutas econômicas, dado que engloba seu entorno cultural.

\section{Entendendo os teatros negros de dentro para fora}

Na busca em conceituar o que são os teatros negros, encontramos referências relevantes para definir o termo no Brasil, sobretudo por estudiosos e fazedores, tais como Christine Douxami (2001), Ricardo Gaspar Müller (1988), Evani Tavares Lima (2010) e Marcos Antônio Alexandre (2017).

Os elementos que compõem os afrocênicos são postos na cena e criam uma poética própria, autorrepresentativa. Essa poética é a produção e execução da arte teatral que configura elementos para seus valores religiosos, culturais e sociais, usando da sensibilidade artística para encenar mundos reais ou não, além de confrontar os monstros sociais, conclamando a sociedade do seu tempo para repensar sobre os moldes préestabelecidos historicamente.

No olhar de Christine Douxami (2001), no texto Teatro negro: a realidade de um sonho sem sono, o sentido de teatro negro, ou teatros negros, passa por contexto vários, entre eles: "pode tanto ser aplicada a um teatro que tenha a presença de atores negros, quanto aquele caracterizado pela participação de um diretor negro, ou, ainda, de uma 
produção negra. Outra definição possível seria a partir do tema tratado nas peças" (DOUXAMI, 2001, p. 1).

Nas palavras de Marcos Antônio Alexandre (2017), que é professor e pesquisador, além de ator e diretor, no livro $O$ teatro negro em perspectivas: dramaturgia e cena negra no Brasil e em Cuba, entende-se teatro negro como:

\begin{abstract}
Textos dramáticos e/ou espetaculares em que os negros, a sua cultura e a sua visão ideológica do (e para o) mundo aparecem como temática central e como agentes[...] .O teatro negro não só retrata as especificidades dos sujeitos negros e sua integração na sociedade, mas também se retroalimenta dos elementos que compõem e integram a cultura dos afrodescendentes em suas distintas manifestações artístico-performáticas: danças, músicas, jogos, linguagem, mitos, religião e ritos, pois o teatro negro é ritualístico (ALEXANDRE, 2017, p. 28-34, grifos do autor).
\end{abstract}

A definição que melhor conceitua os teatros negros na atualidade, e o teatro negro que o NATA defende, é a que Evani Tavares Lima (2010) argumenta em sua tese de doutoramento. Visto que para entendermos o teatro negro precisamos compreender a complexidade da qual está pautado. Nessa perspectiva, é concebido como:

[...] o teatro cuja base fundamental é a afirmação da identidade negra, associada a proposições estéticas de matriz africana, embasadas em questões existenciais e político-ideológicas negras. A perspectiva com a qual trabalhamos é que o teatro negro, da maneira como se configura, instaura uma reflexão inusitada no teatro brasileiro, no que diz respeito à práxis e estética cênicas; à animação e tratamento corpo-vocal do ator; a partir de elementos e abordagens fundados na cultura de matriz afro-brasileira (LIMA, 2010, p. XVII, grifos da autora).

A perspectiva de um teatro afrodiaspórico, embasado nas experiências históricas da população afro-brasileira, com o propósito de contestar e desconstruir o racismo e suas ramificações, possibilita olhares outros para a temática. Um teatro que problematiza a construção histórica e os modelos sociais vigentes a partir de uma dramaturgia decolonial, ou seja, que busca a partir de suas experiências de mundo produzir uma arte que dialogue com suas realidades, ou ainda, uma dramaturgia que traga para a cena as culturas negras, são ideias do teatro negro de maneira ampla. 


\section{NATA: uma política afirmativa para além da cena teatral}

O NATA e a figura da Onisajé se misturam. Nesse sentido, cabe conhecermos a matriarca do NATA, sua formação acadêmica e relação com a arte, para que possamos entender melhor os caminhos que o Núcleo percorre.

Onisajé nasceu em 27 de novembro de 1979 na cidade de Alagoinhas, interior da Bahia, a 124 km de Salvador. Possui graduação em Direção Teatral pela Escola de Teatro da Universidade Federal da Bahia (UFBA), com a montagem do espetáculo Ogum: deus e homem (2010). Tendo obtido o título de mestre pelo Programa de Pós-Graduação em Artes Cênicas da UFBA (PPGAC/UFBA), com a dissertação Ancestralidade em cena: candomblé e teatro na formação de uma encenadora (2016), e atualmente é doutoranda pelo mesmo programa.

Tem, portanto, experiência na área de artes, com ênfase em direção teatral, é também pesquisadora sobre o candomblé, e yakekerê do Ilê Axé Oyá Ladê Inan, tendo sido iniciada na religião do candomblé para o Orixá Omulu na cidade de Alagoinhas.

Onisajé poderia ser mais uma moradora de Alagoinhas que pouco compreende sua condição de mulher, negra, lésbica e de santo, em uma sociedade com pensamento patriarcal, racista, sexista, misógina e intolerante religiosamente, mas não, Onisajé usa de sua arte para promover a reflexão contra todas as formas de discriminação, posicionandose diariamente na sociedade, informando que existe, que tem voz e que vai falar sobre o negro, e que pretende descentralizar o poder vigente por meio das artes cênicas, mais que isso, procura instrumentalizar a população negra por meio de reflexões e debates no meio artístico e acadêmico.

A encenadora e dramaturga emerge de uma cidade pequena no interior da Bahia para, por meio das artes cênicas, mostrar-nos como a minoria em direitos pode contribuir para desconstrução de um discurso desigual, e isso é observado em suas falas nas entrevistas e nas escolhas cênicas. Cabe ainda mencionar que Onisajé foi a primeira mulher negra a dirigir um espetáculo da Cia de Teatro da UFBA. E ao chegar nesse espaço de poder, a encenadora monta o espetáculo Pele negra, máscaras brancas (2019), encenando a obra de Fanon (2010), de mesmo nome. Falando sobre racismo e indo além, colocando uma atriz transexual para viver o filósofo. 
O NATA já tinha essa abreviatura desde a sua formação em 1998, visto que seu primeiro nome foi Núcleo Amador de Teatro e Artes, e passa a ser definido como Núcleo Afro-brasileiro de Teatro de Alagoinhas em 2009. Isso já nos mostra o posicionamento político de Onisajé ao propor um teatro que estava pautado nas questões raciais e na historicidade e legado da cultura africana e da religiosidade afro-brasileira, o candomblé.

Após iniciar o curso de direção teatral em 2006, Onisajé já tinha outra percepção, comprometida com sua cultura, seu povo e suas origens, e a partir de 2009, com outro olhar, como consta do histórico do grupo, cedido para a pesquisa, e o qual utilizo aqui como fonte, argumenta que: “ O grupo tem essa temática como norteadora do discurso estético e político com foco de colaborar na luta contra o racismo e na desmistificação da imagem negativa que a mídia reproduz das religiões e costumes afro-brasileiros". (BARBOSA, [s.d])

Além do eixo central no combate ao racismo e toda forma de discriminação sócioracial que o NATA possui, outras medidas foram e são tomadas ao longo desses 20 anos de fundação, de forma subjetiva, influenciada pelo Teatro Experimental do Negro e Abdias Nascimento e, de maneira objetiva, por artistas e grupos de seu tempo. Dessa forma, o NATA sempre propôs um olhar sobre tais questões fora do palco.

\begin{abstract}
Nesse sentido, o grupo NATA também ministrou oficinas de preparação de atores e seminários nas cidades de Alagoinhas, Salvador e Rio de Janeiro, voltadas para a cena negra brasileira, aumentando seu valor neste cenário. A necessidade de parceiros fez com que o Núcleo estreitasse vínculos com outros artistas, como Thiago Romero, Susan Kalik, Thiago Gomes, Marcelo Jardim, Zebrinha, Jarbas Bittencourt, Márcio Meirelles, Chica Carelli, Luiz Marfuz, Hilton Cobra, Ângelo Flávio, Marilza Oliveira, Gustavo Mello, Sanara Rocha, Deilton José, Luiz Guimarães, Fernando Santana, Cosme Lucian, artistas que inspiram o grupo e também trabalharam como parceiros em espetáculos como "Siré Obá" "A festa do Rei" e "Ogum Deus e Homem", além do Babalorixá Márgio Luiz e a Yalorixá Roselina Barbosa que juntos são os orientadores litúrgico-antropológicos do grupo nas questões sobre candomblé, valorizando sempre as alianças e afinidades também com outros grupos como O Bando de Teatro Olodum, Cia dos Comuns, CAN e participando também de eventos relevantes na luta contra o racismo e na valorização da arte e do artista negro como as três edições do Fórum Nacional de Performance Negra realizados pela Cia dos Comuns e o Bando de Teatro Olodum, I Festival de Teatro do Subúrbio e em duas edições do Festival "A Cena Tá Preta" realizado pelo Bando de Teatro Olodum (BARBOSA, [s.d]).
\end{abstract}

Notamos, portanto, que Onisajé, enquanto encenadora, e o grupo NATA, para além do palco, abrem portas para outros artistas pensarem a arte negra, e mais, o diálogo 
que mantêm com grupos de teatro como o Bando de Teatro Olodum, Cia dos Comuns e Cia Abdias Nascimento demostra a preocupação de conexão com o empoderamento negro e de luta. Sem deixar de aferir a atuação do NATA em projetos, oficinas e cursos que, além de trocar conhecimento sobre teatro, aproveita a oportunidade para discutir temas como racismo e preconceito religioso.

Diante do que já foi apresentado, ficam mais evidentes algumas características do NATA enquanto grupo dentro no contexto dos teatros negros. Ele é um teatro ritualístico, e veremos que não somente pela escolha em dialogar com as divindades do candomblé, mas pelo processo cênico, de passar pelas etapas de pesquisa, de ouvir história dos mais antigos, em procurar sentir o corpo em cena, e, principalmente em não escolher um ator para viver um personagem, mas deixar que o arquétipo da divindade se aproxime do corpo do ator, ou seja, das características que o ator possui. É um teatro engajado característica que perpassa todos os grupos de teatro negro - político, procurando entender sua historicidade e ancestralidade.

Além disso, o teatro do NATA é afrocentrado, ou seja, um teatro que bebe da fonte da sua ancestralidade africana, que se assenta sobre a cosmo-percepção dos povos saídos das Áfricas negras. Conversa muito com a perspectiva de afrografia de Leda Maria Martins (1997), que, em sua Afrografias da memória, refere-se à ligação entre a população afro-brasileira e as memórias africanas.

O teatro do NATA pode ser lido ainda como um teatro que passeia pelos vários estilos dramatúrgicos, ou seja, épico, lírico, dramático em um único espetáculo; e que trabalha com múltiplas linguagens artísticas, como a dança, música, ou seja, é um teatro multilíngue, pois compreende que o conhecimento é fluido e assim é a arte, não precisa ser separada em categorias isoladas. 


\subsection{NATA: 0 candomblé e o atuante $^{3}$ nas artes cênicas}

Nesse horizonte de diálogo entre arte negra e candomblé, vale historicizar as casas de axé, e nesse recorte, ao conceituar e fundamentar o que é candomblé, Ari Lima e Nana Luanda M. Alves argumentam:

Neste sentido, recusamos definir e categorizar o candomblé como uma "religião de matriz africana". Em vez disso, inspirados na definição de Sidney Mintz e Richard Price (2003), para uma "cultura afro-americana", preferimos referi-lo como uma religião de orientação africana. Ou seja, por um lado, acreditamos que esta religião se formou e permaneceu ao longo da história através do empenho de africanos e descendentes que, no Brasil, reconstituíram laços de parentesco, assim como rituais e mitos de deuses originalmente cultuados em África. (LIMA; ALVES, 2015, p. 586, grifos dos autores).

Observam os autores que o candomblé foi forjado tanto historicamente quanto cultural e socialmente dentro do modelo colonialista português, sendo pensado dentro dos três longos séculos de escravidão e da hegemonia branca. Sendo inevitável não olharmos para a África, porém não podemos reger a prática histórica, cultural e social do continente africano, senão a de seus descendentes em contextos outros.

Quanto ao candomblé na cidade de Alagoinhas, local onde o NATA surge, e onde Onisajé se torna yakekerê, Priscila Nascimento (2012), historiciza que:

Em Alagoinhas, durante muito tempo, prevaleceram os terreiros da nação angola. Esta supremacia banta começou a sofrer modificações em torno dos anos 1990, quando começam a chegar à cidade os primeiros terreiros ketu. Apesar de terem sido inicialmente rejeitados pela comunidade de terreiro alagoinhense, o modelo ketu rapidamente se espalhou. Não houve uma leva de novos terreiros sendo fundados, mas redefinições identitárias. Os terreiros identificados com o modelo angola vão, pouco a pouco, adaptar-se a esta nova nação (NASCIMENTO, 2012, p. 32).

Quanto ao terreiro ketu, o Ilê Axé Oyá Ladê Inan, Lima e Alves nos contam:

Fundado em 2008. Neste terreiro, foram realizadas visitas de observação e entrevistas com a chefa da casa e seus outros membros: filhos de santo, iniciados e frequentadores. A escolha se deu pelo perfil dos membros do Ilê Axé Oyá Ladê Inan. A maioria desta são artistas ou pessoas ligadas à arte. No terreiro há também grande circulação de intelectuais, acadêmicos e pessoas

\footnotetext{
3 "Atuante" é um termo para definir um ator que não está preso ao conceito ocidental de atuação, pois dialoga com a encenação, a música e as danças, sendo assim, é um sujeito que atua, dança e canta nos espetáculos. A definição é proposta por Onisajé em sua construção como pesquisadora e artista da cena.
} 
com acesso a outros conhecimentos - o que difere de certa maneira das demais casas observadas (LIMA; ALVES, 2015, p. 587).

Como resultado das pesquisas, os autores de ambos os trabalhos, chegaram à compreensão de que o candomblé não é limitado pelo seu sistema de fé, mas também envolve toda sua importância cultural herdada, seu dinamismo; dessa forma, o candomblé deve ser compreendido amplamente, composto de crenças, obrigações de fé e o contexto dos integrantes com o meio social em que vivem.

Por esses entendimentos, compreendemos o motivo de o candomblé, antes e após a abolição da escravidão, servir de diálogo entre outra forma de fé, diferente da hegemônica (católica/cristã), levando em consideração sua ancestralidade, historicidade, ou seja, suas memórias e sua relação social, passado e presente. Sendo majoritariamente formado por negros, o candomblé como religião afro-brasileira serve como local de luta contra as forma de discriminação racial.

Por esse ângulo, faz-se notável que a religião pode e deve ser entendida como prática que compreende as múltiplas vivências e mutações histórico-sociais da existência dos negros. Entende-se o candomblé para além da configuração de fé, sendo pensado como local de resistência e de resgate das memórias, assim como são os teatros negros.

Por essas razões, é compreensível o diálogo proposto pelo NATA entre teatro e candomblé. Vista a sua percepção de religião como lócus de resistência, assim como a arte negra, que busca sua negritude e ancestralidade na cena, combatendo o racismo e discriminação religiosa, tendo um papel importante na criação e na definição da própria identidade sociocultural dos afrodescendentes.

\subsection{A poética afrocênica do NATA}

Meninas e meninos brasileiros acabam conhecendo logo nos anos iniciais na escola, ou ainda em casa, histórias e personagens da mitologia greco-romana, passando pelo ensinamento da Grécia antiga como "berço da civilização ocidental”, porém pouco se fala, ensina e aprende sobre Áfricas. Nesse sentido, nem todos os brasileiros conhecem ou foram apresentados à mitologia dos orixás. 
Orixás no candomblé ou na umbanda são divindades ligadas à natureza, são seres que vivem no plano espiritual. Contudo suas origens se dão no plano físico, e suas denominações resultam de demarcação territorial do continente africano. Como é o caso da mitologia dos Iorubás, que passa pela construção do mundo e das crenças que surgiram onde hoje provavelmente é a região da Nigéria e República do Benin. Porém é importante reafirmar que essas religiões, como as entendemos hoje, surgiram no Brasil.

Clyde W. Ford, diretor e fundador do Instituto de Mitologia Africana em Washington, escreveu o livro O herói com uma face africana: mítica sabedoria da África tradicional, Bantam (2000). No livro, Ford apresenta a ideia do mito e história, apontando:

Essas aventuras de heróis (ou divindades) são mais do que o enredo da história, elas falam, por metáforas, da aventura humana pela vida. Os desafios do herói são nossos. Assim, muitos traços que o herói demonstra para responder os desafios da jornada simbolizam aqueles recursos pessoais a que todos nós devemos recorrer para enfrentar os desafios da vida (FORD, 2000, p. 82).

Outro autor importante para a discussão é Reginaldo Prandi (2001), que reuniu no livro Mitologia dos orixás, mais de 100 títulos de contos e mitos iorubá e afro-americano. Para Prandi, dentro das religiões afro-brasileiras, sobretudo de tradição Iorubá, os mitos têm grande importância, sendo vistos como símbolos que atingem o passado, o presente e o futuro.

Prandi (2001) argumenta sobre o contexto do universo dos orixás e sua ligação com o homem: "Alegram-se e sofrem, vencem e perdem, conquistam e são conquistados, amam e odeiam. Os humanos são apenas cópias esmaecidas dos orixás dos quais descendem" (PRANDI, 2001, p. 24). Nessa perspectiva, observa-se como essas histórias vão apontar os aspectos da vida humana - amor, paixão, brigas, guerras, conquistas e derrotas - , e por essas razões, os orixás são de grande valor na visão de mundo dos Iorubá.

Para compreender a poética cênica do NATA, ponderando a junção entre o teatro e o candomblé, que norteia e desenvolve o processo político/criativo do grupo, referencio o espetáculo Exu - a boca do universo (ARCADES; BARBOSA, 2014). Também tomo como base a escrita de Onisajé no texto Ancestralidade em cena: o teatro do NATA (BARBOSA, 2015), e a série de documentários Entrenós (2018), que procura investigar 
o processo criativo e cênico de artistas brasileiros, sendo que em uma das suas temporadas, dedicou um capítulo para tratar sobre o NATA.

Nos 20 anos de trabalho, o NATA além de fazer montagens de espetáculos, leituras dramáticas e movimentar os espaços da arte teatral, tem promovido oficinas e debates em Alagoinhas, Salvador e no Brasil, fomentando um diálogo com a valorização da cultura negra brasileira.

Nossos espetáculos possuem, como eixo norteador, a história, a cultura e a religiosidade afro-brasileira, com o objetivo de desmistificar os preconceitos e as imagens pejorativas que povoam, histórica e culturalmente, o imaginário coletivo da sociedade, resultantes de um processo de colonização e racismo (BARBOSA, 2015, p. 87).

No campo de valorização da cultura e da religiosidade afro-brasileira, o NATA faz uma homenagem justa e muito representativa aos orixás e às casas de axé por meio do que a yakekerê chama de: "Orikis (poesias em exaltação aos orixás)" (BARBOSA, 2015, p. 87). Os espetáculos são concebidos tanto esteticamente como dramaturgicamente a partir do que acontece nos rituais dos terreiros de candomblé.

O NATA concebe, em 2014, Exu: a boca do universo, que foi o primeiro espetáculo a refletir a cultura negra em diálogo com o candomblé, apoiado pelo programa de manutenção artística do Teatro Castro Alves (TCA). ${ }^{4}$

O objetivo era a celebração da vida, contando a história da divindade Exu de forma oposta ao que foi transmitida na cultura ocidental. Esse Orixá é pensado no espetáculo como ser libertador e é enfatizado todo seu gerenciamento para as comunicações no candomblé.

O espetáculo Exu - A Boca do Universo foi a ação culminante do projeto Exu Silé Oná TCA - Exu abre os caminhos do novo TCA, projeto vencedor do Edital TCA-Núcleo "Em Construção" - Edição Especial 2013/Uma Homenagem a Lina Bo Bardi. Nesta edição, o edital consistia na realização de uma ocupação artística de cinco meses, onde o grupo selecionado faria parte da programação do teatro, com diversas atividades, além das apresentações dos espetáculos de repertório e a estreia da nova montagem do grupo (BARBOSA, 2015, p. 97).

\footnotetext{
${ }^{4}$ A dimensão a ser pensada aqui sobre o espetáculo "Exu" é da importância do projeto "Exu Sile Oná" na ocupação do espaço do Teatro Castro Alves. Um teatro tradicional que viabiliza um edital, no qual a cultura negra pode ser evidenciada. E essa dimensão precisa ser pensada no tocante ao projeto desenvolvido ao longo dos 5 meses de instalação do NATA no TCA. Com 28 atividades artísticas culturais sendo executadas.
} 
Exu: a boca do universo objetiva desconstruir a visão de Exu na sociedade, que por muito tempo, desde a chegada dos nagôs ao Brasil, mas principalmente ao longo do século XIX, foi apontado como uma figura demoníaca, ou seja, Exu recebeu o estigma de demônio, algo ruim e do mal. Assim nos conta Onisajé:

Queríamos montar um espetáculo que contribuísse com o processo de quebra dos estigmas seculares que foram imputados a ele e que povoam o imaginário social a seu respeito. Tratava-se de realizar uma montagem que divulgasse a história desse Orixá, seus atributos de mensageiro, comunicador, fiscalizador da verdade, amante da vida e apaixonado por Oxum (BARBOSA, 2016, p. 116).

Portanto, ao encenar sobre Exu, o NATA aponta para o futuro na busca em descontruir o estereótipo sobre o orixá, ao tempo que nos relembra de um passado o qual estava, e que podemos dizer que ainda permanece, pautado na discriminação religiosa.

\footnotetext{
Nesse sentido, o Núcleo Afro-brasileiro de Teatro de Alagoinhas se dá conta de como as indagações sobre o teatro ritualístico com apoio das danças e músicas africanas e pertencentes à cultura afro-brasileira, poderiam ser apresentadas e problematizadas na cena teatral baiana. Portanto, pensar o candomblé e a arte, e perceber todos esses elementos presentes em ambos foi o desejo do NATA e de Fernanda Julia. Levando para a cena [...]a história dos nossos antepassados africanos, através do nosso ponto de vista e da nossa visão de mundo, realizando um fazer teatral desde dentro para fora (BARBOSA, 2015, p. 97).
}

A ideia de um teatro de dentro para fora aparece na escrita de Onisajé. Nessa ideia, o espetáculo Exu ancora-se na luta política do grupo NATA. Visto que a peça tem como foco falar da ancestralidade negra, de poesia, de beleza, da força, e claro, de luta. A luta nem sempre aparece de forma explícita nos espetáculos, porém a própria existência e resistência do NATA em ocupar esses espaços, já é a luta.

O espetáculo Exu foi apresentado na área livre do TCA, quebrando com o tradicional modelo grego de encenação. Pondo os espectadores em volta do cenário e dos atores. Criando um círculo, uma roda. Esse contexto é interessante para pensarmos como o teatro negro não está preso aos modelos ocidentais do fazer teatral. $\mathrm{O}$ teatro negro do NATA rompe com a lógica padrão de ocupação do TCA ao encenar fora das salas de espetáculos. O que resulta após longa temporada, e nesse caso, não só no TCA, mas também em outros espaços da cidade, mais de 2.500 espectadores. 
O historiador Jaime Sodré (2009), no artigo Exu, a forma e a função, reflete sobre a concepção preconceituosa do orixá na sociedade brasileira, e é justamente essa ideia que o NATA com o espetáculo Exu procura desconstruir. Assim como o historiador, o NATA compreende Exu como representação da cultura negra, e por essa razão foi demonizada pela cultura branca.

Exu assume todos esses atributos e mais a revolta de uma cultura de resistência
contra os valores impostos pela sociedade dominante. Isto é, o Hermes africano
reúne em si mesmo os elementos de uma metáfora expressiva que simboliza a
cultura negra num ambiente hostil: esta para sobreviver e se afirmar, serve-se
do símbolo antagônico por excelência da religião dominante, para veicular uma
visão de mundo própria onde a ênfase é posta na contestação (SODRÉ, 2009,
p. 10).

A luta do NATA aparece mais uma vez ao compreendermos o porquê falar sobre orixás como Exu; o porquê é necessário descontruir a carga negativa que as divindades receberam ao logo dos tempos, e o porquê os teatros negros são teatros de luta por definição. É resistir para não sumir. É resistir para existir.

É necessário perceber a cultura afro-brasileira, entender como essa diversidade está presente em nossa sociedade e história. Nessa perspectiva, é fundamental vermos o protagonismo desses agentes da arte. Visibilizando essa cultura múltipla e rica, e nada melhor que se valorize a prática teatral feita por negro.

Pensadores como Abdias Nascimento (2004) e o coletivo NATA dialogam quando afirmam que o movimento de dentro para fora contribui para a emancipação e transformação do negro, dando voz aos grupos que ao longo da história foram silenciados, negligenciados, sobretudo, para que tenham consciência de sua importância identitária, sabendo de onde vieram e percebam suas práticas e costumes, encontrando-se nessa sociedade e sentindo-se pertencente a ela, tendo o reconhecimento do seu valor.

Para além do sentido religioso e da fé, o candomblé, nesse contexto, contribui para o fortalecimento do sentido de pertencer - de fazer parte de um grupo, de uma cultura, de um lugar. É reconhecer sua história ancestral. Essa é a importância para um grupo social que foi marginalizado, que foi marcado pela violência no processo escravista e depois desigual. Para tanto, é da maior importância o legado desses artistas e coletivos negros como o NATA, contribuindo para os negros se empoderarem, a assumirem seu lugar na sociedade, na arte e nos espaços de poder. 
A série documentária Entrenós (2018), que mencionei no começo desta seção, foi de grande importância para o aprofundamento desta análise que expõe a comunicação entre candomblé e arte, tendo em vista que a série foi documentada em agosto de 2017, no terreiro de candomblé do qual Onisajé faz parte, Ilê Axé Oyá Ladê Inan, em sua cidade natal.

A proposta do diretor, que passou uma semana acompanhando Onisajé, é apontar o processo cênico do NATA e sua relação entre arte e religião. No documentário, Onisajé, em meio ao processo para a festividade da Cabocla Jurema, comenta a importância das folhas, dos aromas tanto para o candomblé como para o palco cênico.

Ao comentar sobre o trabalho do ator, Onisajé como diretora, argumenta que a proposta é sempre procurar empretecer esses atores. O verbo "empretecer" utilizado "refere-se ao contato, mais que isso, apropriação, entendimento, pertencimento das questões raciais" (ENTRENÓS, 2018). Onisajé argumenta que:

\footnotetext{
Quando o ator entra em cena, ele não está sozinho. Carrega em cada partícula do seu corpo a história, a cultura e os valores de onde veio. Mesmo sem raciocinar muito sobre isso, a sua simples presença em cena fala muito de um determinado lugar, de determinadas pessoas e seus respectivos costumes (BARBOSA, [s.d]).
}

Essa é a ideia que a Onisajé compreende quando se refere ao processo de empretecer os atores, ou seja, entender que esses atores em cena são políticos por natureza, e cabe elucidar esses agentes das artes para possuírem um discurso em diálogo com sua realidade de artista negro.

No processo de preparação dos espetáculos, tanto conceitual como imagético, Onisajé comenta que o grupo se junta, lê o texto, assiste a documentários e tudo que tem relação com o tema em questão. Dessa maneira, no NATA, todos participam, interagem, contribuem, dividem suas experiências e conhecimentos sobre a temática e sobre o recorte escolhido.

A próxima etapa de construção dos espetáculos são os rituais, que são divididos em dois momentos. O primeiro é o ritual litúrgico, que é o ato de ir ao candomblé, referenciar os orixás, fazer oferendas, como por exemplo, deixar comida para as divindades, tomar banhos de folhas, assim como vivenciar o dia a dia, a prática cotidiana do Ilê Axé Oyá Ladê Inan, observar os mais antigos, ouvir histórias sobre os orixás. 
O segundo ritual é o artístico, que compreende separar os orixás por elementos primordiais da natureza (terra, ar, água e fogo), pois cada divindade tem um elemento fundamental. A encenadora ainda complementa "que é um ritual artístico porque mesmo tendo um princípio religioso, sua função é povoar o corpo, a emoção, e a mente dos atores e da equipe como todo, de referências sensoriais" (ENTRENÓS, 2018).

O próximo estágio é assumir a sala de ensaio. Tendo uma imagem norteadora, os/as atuantes procuram vivenciar a prática artística para provocar sentimentos e sentidos, criando significados, formando cenas a partir dos jogos cênicos, relação ator/texto, contexto, direção, música, ambiente etc. São essas perspectivas que norteiam o NATA, no sentido de aprofundar a linguagem do teatro negro com objetivo de sair das cercas do racismo. Onisajé afirma que para ela "o teatro negro é o teatro de militância contra o racismo e toda forma de opressão racial do negro" (ENTRENÓS, 2018).

Entendemos aqui que são teatros negros, no plural. O NATA apresenta uma das vertentes da arte negra, de retratar a religião, e unir teatro e candomblé. Para a arte negra, assim como é para o teatro negro, falar do candomblé não é uma tarefa fácil. E assim como foi/é a luta de tantos outros artistas, grupos e coletivos negros, é a luta do NATA.

Para Onisajé, fazer teatro negro é mais que chegar a um lugar; o seu valor encontra-se na própria caminhada — da mesma forma como é ser yakekerê de um ilê de candomblé. Para os artistas do NATA, a relação teatro e candomblé provocou um encontro identitário. O candomblé, para além da perspectiva religiosa e de fé, possibilitou à encenadora um norte. O que é visto, sentido, dito, pensando nos espetáculos do NATA é resultado dessa cosmovisão, na qual se preocupa com a caminhada e com formas de desconstruir qualquer visão negativa sobre a cultura negra. O palco e o terreiro do candomblé são, portanto, territórios de representatividade.

\section{Considerações finais: o teatro pede asè}

Ancestralidade negra e arte caminham juntas nas criações cênicas que a yakekerê Onisajé desenvolveu ao longo desses vinte anos, tendo em vista a importância do candomblé como eixo norteador na encenação, entendendo que sua posição de sacerdotisa e artista da arte dramática a coloca no caminho de mão dupla, com problemáticas e 
reflexões no tocante à identidade afro e à arte, compondo um olhar de diferenças e semelhanças. E é esse contexto que enriquece os processos cênicos do NATA.

O teatro produzido pelo NATA tem sua importância, principalmente por propor outros olhares para o negro na cena. A forma que Onisajé, como encenadora, procura combater o racismo e discriminação religiosa é apresentando espetáculos com temática própria, dramaturgia concebida a partir dos referenciais ancestrais de Áfricas, é promovendo um trabalho de pesquisa ostensiva, mostrando para o público como a cultura negra é também composta de saberes múltiplos.

Teatros negros, no plural, são territórios de representatividade, da forma de viver e ser dos indivíduos negros do Brasil; é espaço de empoderamento dos fazedores da arte, que vão emergir como sujeitos históricos e não mais como meros objetos cenificados. Protagonistas de suas histórias e trajetórias, não mais, coadjuvantes do outro.

Para o NATA, ou ainda, para tantos grupos que produzem a arte negra, não só no teatro, mas na música, dança, literatura, o obstáculo é o mesmo - o mito da democracia racial, ou ainda mais, o próprio racismo vivido na pele, na carne e na alma, com suas raízes fincadas na historicidade do Brasil. Portanto, para os grupos de teatro negro, cabe um forte diálogo entre a produção artística e um discurso político ancorado na luta negra.

Portanto podemos aferir que o teatro é o reflexo da sociedade e de suas construções históricas, ao tempo que é o espelho interno que motiva transcender o já dito. Conceber uma cena teatral nacional, diante dos entraves impostos pelo imperialismo estético - leia-se cultural, em que se enxerga e entende beleza por meio único da brancura, como cânone centralizador —, é apenas uma das muitas formas, haja vista a formação do povo brasileiro e da pluralidade das expressões artísticas/culturais do Brasil.

A cena é ajustada para a vivência negra, sendo assim, é o teatro plural, visto que abraça as múltiplas identidades dos negros. São teatros de conflitos e lutas por definição. São teatros de insubordinação, bem diferente do local de subalternidade dado historicamente aos negros. São teatros políticos, sociais, étnicos, religiosos e ancestrais. São teatros-quilombos urbanos: do interior para o exterior. 


\section{Referências}

A ELEIÇÃO. Direção: Onisajé. Dramaturgia: Lurdes Ramalho. Ano: 2005

ALEXANDRE, Marcos Antônio. O teatro negro em perspectiva: dramaturgia e cena negra no Brasil e em Cuba. Rio de Janeiro: Editora Malê, 2017.

ARCADES, Daniel. BARBOSA, Fernanda Júlia. Espetáculo: Exu - a boca do universo. Núcleo Afro-Brasileiro de Teatro de Alagoinhas (NATA), 2014. Texto registrado pela Fundação da Biblioteca Nacional.

BARBOSA, Fernanda Julia. Ancestralidade em cena: candomblé e teatro na formação de uma encenadora. 2016. Dissertação (Mestrado em Artes) — Universidade Federal da Bahia, Salvador, 2016.

BARBOSA, Fernanda Julia. Ancestralidade em cena: o teatro do NATA. Repertório, Salvador, n. 24, p. 86-97, 2015. Disponível em: https://periodicos.ufba.br/index.php/revteatro/article/ view/14832/10177. Acesso em: 22 abr. 2021.

BARBOSA, Fernanda Julia. Onisajé [Histórico do NATA], disponibilizado pelo grupo para a pesquisa em 30 nov. 2020). [s.d]. Mimeo.

CHARTIER, Roger. O mundo como representação. Estudos Avançados, São Paulo, v. 5, n. 11, p. 173-191, 1991. Disponível em: https://www.scielo.br/scielo.php?script=sci_arttext\&pid=S010340141991000100010. Acesso em: 22 abr. 2021.

DOUXAMI, Cristiane. Teatro negro: a realidade de um sonho sem sono. Revista Afro-Ásia, v. 25, n. 26, p. 281-312, 2001. Disponível em: https://periodicos.ufba.br/index.php/afroasia/ article/view/21016. Acesso em: 22 abr. 2021.

ENTRENÓS, série documentária. Direção: Pablo Polo, $2^{a}$ temporada. Episódio: Onisajé. Duração: 26 min. Ano: 2018. Disponível em: https://canalcurta.tv.br/filme/?name=onisaje. Acesso em: 10 dez.2018.

FANON, Frantz. Pele negra, máscaras brancas. Salvador: EDUFBA, 2010.

FORD, Clyde W. O herói com rosto africano: mitos da África. São Paulo: Selo Negro, 2000.

GUARDA-ROUPA íntimo. Direção: Onisajé. Dramaturgia: NATA. Ano: 1999

HALL, Stuart. A identidade cultural na pós-modernidade. 11. ed. Rio de janeiro: DP\&A Editora, 2010.

LIMA, Ari; ALVES, Nana Luanda M. Relações raciais, racismo e identidade negra no candomblé baiano de Alagoinhas. Revista de Educação, Cascavel, v.10, n. 20, p. 585-598, 2015. Disponível em: http://e-revista.unioeste.br/index.php/educereeteducare/article/view/12599. Acesso em: $22 \mathrm{abr}$. 2021.

LIMA, Evani Tavares. Um olhar sobre o teatro negro do teatro experimental do negro e do bando de teatro olodum. 2010. Tese (Doutorado em Artes) - Instituto de Artes, Universidade Estadual de Campinas, Campinas/SP, 2010.

MARTINS, Leda Maria. Afrografias da memória: o reinado do rosário do jatobá. São Paulo: Perspectiva, 1997.

MÜLLER, Ricardo Gaspar. (Org.). Dionysos especial: Teatro experimental do negro. Rio de Janeiro: FUNDACEN, 1988. 
NASCIMENTO, Abdias. Teatro experimental do negro: trajetória e reflexões. Estudos Avançados. São Paulo, v. 18, n. 50, p. 209-224, 2004. Disponível em: https://www.scielo.br/ scielo.php?script=sci_arttext\&pid=S0103-40142004000100019. Acesso em: 22 abr. 2021.

NASCIMENTO, Priscila Dias do. O candomblé de Alagoinhas: entre o modelo nagocêntrico e a intolerância religiosa. Uma discussão sobre o campo religioso alagoinhense. 2012. Trabalho monográfico (Graduação em Artes) — Universidade Estadual da Bahia, Alagoinhas, 2012.

O SECO da Seca. Direção: Onisajé. Dramaturgia: NATA. Ano: 1998.

OGUM - deus e homem. Direção: Onisajé. Dramaturgia: Onisajé e Fernando Santana. Ano: 2010

PELE Negra, máscaras brancas. Direção: Onisajé. Dramaturgia: Aldri Anunciação. Ano: 2018.

PERFIL. Direção: Onisajé. Dramaturgia: NATA. Ano: 2004

PRANDI, Reginaldo. Mitologia dos orixás. São Paulo: Companhia das Letras, 2001.

SENZALA. Direção: Onisajé. Dramaturgia: NATA. Ano: 2002

SKIDMORE, Thomas E. Preto no branco: raça e nacionalidade no pensamento brasileiro. Rio de Janeiro: Paz e Terra, 2012.

SODRÉ, Jaime. Exu: a forma e a função. Revista VeraCidade, Salvador, ano 4, n. 05, p. 1-11, 2009. Disponível em: http://www.veracidade.salvador.ba.gov.br/v5/pdf/artigo4.pdf. Acesso em: 22 abr. 2021.

TÁ na cor. Direção: Onisajé. Dramaturgia: NATA. Ano: 1999

Recebido em: 25/01/2021.

Aceito em: 08/04/2021. 